\title{
Escaping from the ghetto
}

\author{
Author: \\ Vincent Brümmer ${ }^{1,2,3}$ \\ Affiliations: \\ ${ }^{1}$ Faculty of Theology, \\ University of Utrecht, \\ The Netherlands \\ ${ }^{2}$ Department of Systematic \\ Theology, University of \\ Stellenbosch, South Africa \\ ${ }^{3}$ Research associate, \\ Department of Dogmatics \\ and Christian Ethics, \\ University of Pretoria, \\ South Africa

\section{Correspondence to:} \\ Vincent Brümmer \\ Email: \\ vincent.brummer@gmail. \\ com \\ Postal address: \\ Valklaan 1, 3722ZJ \\ BILTHOVEN, The Netherlands \\ Dates: \\ Received: 13 Apr. 2012 \\ Accepted: 22 May 2012 \\ Published: 06 Dec. 2012 \\ How to cite this article: \\ Brümmer, V., 2012, Escaping \\ from the ghetto, Verbum \\ et Ecclesia 33(2), Art. \#729, \\ 7 pages. http://dx.doi/ \\ org/10.4102/ve.v33i2.729
}

(c) 2012. The Authors.

Licensee: AOSIS

OpenJournals. This work

is licensed under the

Creative Commons

Attribution License.
'Revealed theology' claims that religious belief derives from divine revelation and can only be justified in the light of such revelation. This entails a retreat into an intellectual ghetto: Only believers can participate in this kind of theology because only believers have access to divine revelation. The usual alternative to revealed theology is 'natural theology', which tries to prove the truth of (Christian) faith in the light of the universally accessible criteria of reason and experience. It is argued that natural theology fails to provide such proof and therefore cannot liberate theology from the intellectual ghetto of revealed theology. This paper argues for a 'philosophical theology' which analyses the meaning of (Christian) doctrine rather than proving its truth. Since the methods and criteria of this analysis are universally acceptable and not reserved for believers, this form of theology liberates believers from the intellectual ghetto of revealed theology.

\section{Theology in the ghetto}

Like me, Etienne de Villiers studied theology at Stellenbosch. I did so in the 1950s and he in the 1960s. Both of us combined the course in theology with a master's degree in philosophy. At that time, this combination was not without its difficulties. Some of our teachers in theology were rather suspicious of students in theology who also were trained in philosophy. Such students tended to ask difficult questions and seemed to demand a philosophical justification of the theological views put forward by their teachers. According to these teachers, our theological views could only be justified with an appeal to the Bible, and more specifically to the Bible as interpreted within the Reformed tradition. The Bible contains divine revelation, and our theological views should be based on such revelation and not on philosophy. Let us call this view on the justification of religious beliefs 'revealed theology'.

The trouble with revealed theology is that it seems to entail a form of fideism in which Christian theology is withdrawn into an intellectual ghetto. On this view, theologians and believers base their religious truth claims on grounds not accessible to everybody but only to believers who have privileged access to divine revelation. Outsiders who reject the authority of the Bible have no access to such revelation and are therefore unable to determine the truth of religious belief. Sometimes this is extended to include not only the truth but also the meaning of religious claims. Thus for example, Austin (1967) argues that:

the affirmation-negation paradox is of fundamental importance in theology, giving expression to the principle that the religious ultimate is beyond all human concepts, so that what is affirmed of it must also be denied. (p. 49)

Since God in this way transcends our human concepts, religious beliefs also transcend the rules of general logic and have a special paradoxical logic of their own which only believers are able to apply. Believers alone can determine what religious claims mean and what they entail (on the difficulties with this view on religious language, see chapter 2 in Jeffner 1986 and chapter 2 in Brümmer 1992). Believers then not only have privileged access to the truth but also to the meaning of religious claims. By making the criteria for truth and meaning purely internal to faith, this view seems to immunise theology and religious belief from all external criticism. This protection is obtained at a price, however, since it entails that all alternative religious views can claim the same protection. None of them can be criticised from the outside, nor can they criticise each other. The result is an extreme form of religious relativism that I do not suppose the defenders of revealed theology set out to achieve in the first place!

It seems therefore that, in order to avoid these fideistic implications, theologians will have to appeal to common standards of meaning and rationality as these have been developed in philosophy in order to justify the claims they defend. In justifying their beliefs, they must appeal to some basic intellectual meeting-point common to everybody, both believers and non-believers. How are we to set about finding this common intellectual meeting point in terms of which the truth claims of 
Christianity are to be justified? One of the most significant attempts by philosophers at finding such a common ground for religious belief is that proposed by the traditional rival of revealed theology, namely 'natural theology'.

Whilst revealed theology tries to derive the truth claims of religion from a revelation only accessible to believers, natural theology tries to justify religious truth claims by deriving them from universal grounds of reason and experience that are in principle accessible to everybody. In this way, natural theology tries to prove the truth claims of religion by basing them on grounds which are acceptable to both believers and non-believers. As we shall argue in this article, this project of natural theology also faces grave difficulties. On the one hand, it tends to reduce Christian doctrine to the lowest common denominator shared by all forms of theism whilst, on the other hand, it necessarily fails in the end to provide the required universally acceptable grounds to justify believing even this reduced form of theism. In the final analysis, the reasons believers have for accepting Christian doctrine must in some way involve an appeal to revelation. That being the case, how can theology avoid being relegated to an intellectual ghetto? Is it possible to develop a form of theology which avoids retreating into an intellectual ghetto and can nevertheless account for the fact that Christian faith (and mutatis mutandis all other faiths) is in some way or other derived from revelation?

\section{Philosophical theology}

A possible candidate that might be considered here is the kind of 'philosophical theology' defended by Kretzmann. Kretzmann (1989) defines philosophical theology by distinguishing it from natural theology:

I'm using the term 'philosophical theology' in a sense that seems at least on its way to becoming standard, a sense in which it is to be distinguished from natural theology, the other sort of theology that has been practised by philosophers. Natural theology may be broad or strict in its criteria for admissible premises, but its specific characteristic is its refusal to admit as premises any doctrinal propositions that are not also accessible to observation and reason. Supporters of natural theology would explain that it imposes those strictures in order to be able to claim that it can offer proof. Philosophical theology shares the methods of natural theology broadly conceived -i.e. analysis and argumentation of all the sorts acceptable in philosophy and the sciences - but it lifts natural theology's restriction on premises. In particular, philosophical theology accepts as premises doctrinal propositions that are not also initially accessible to observation and reason. From a philosophical point of view, it takes up such premises as assumptions. Argumentation based on such premises may be (and historically have been) as rigorous as any, but the status of its premises of course precludes its satisfying the peculiarly stringent criteria of Aristotelian demonstration. A philosophical theologian engaged in such reasoning tests the coherence of doctrinal propositions, develops their implications, attempts explanations of them, discovers their connections with other doctrinal propositions, and so on, with no pretence at offering proofs of the sort putatively available in natural theology. (pp. 15-16)
According to Kretzmann's definition above, natural theology is an enterprise claiming to achieve knowledge of God that can be justified on generally accessible grounds, that is 'premises accessible to observation and reason'. As I suggested above, there are two serious objections to this enterprise. First of all, knowledge claims about God are impossible without an appeal to revelation, and since revelation is only accessible to those who experience it with the 'eyes of faith', it cannot provide any universally acceptable proof. We will return to this point in more detail under the heading 'Philosophical theology and fideism'. Secondly, in its search for universally acceptable knowledge of God, natural theology tries to defend knowledge claims that are not distinctive for any specific religion but are accessible to all who are endowed with 'observation and reason' (Kretzmann 1989:15). But then, as Kretzmann point out, all central doctrines of any specific religion are beyond the reach of natural theology. Kretzmann (1989) thus claims that:

[a]ll the distinctively Christian doctrines are ... initially inaccessible to observation and reason. And so, because the strictures of natural theology preclude it's considering the doctrines which are the very differentiae of Christianity, the philosophy that is natural theology is at best adjacent to Christianity, not in it. (p. 16)

In appealing exclusively to universally acceptable grounds, natural theology fails to achieve the knowledge of God as distinctive for the Christian tradition. In this way, natural theology falls outside the bounds of classical Christian theology.

In this regard, Schwöbel (1994) has shown persuasively that the kind of natural theology referred to here arose in the 17th and 18th centuries in response to the religious wars and to the renewal of an atheistic critique of Christian faith after the Reformation. Faced with the socially disastrous effects of warring confessional factions in European society, this response tried to produce a common rational theistic concept of God transcending the confessional pluralism of the Christian tradition. This common concept of God could then serve as the basis for unity in European society. The result was:

a de-contextualization of the Christian concept of God which is abstracted from its conceptual setting in the doctrinal scheme of Christian theology and from its context in the practice of Christian faith. (Schwöbel 1994:179)

In this respect, Kretzmann's (1989) philosophical theology is different:

Philosophical theology, the ongoing project of supporting, elucidating, extending, and connecting propositions of Christian doctrine by the standard philosophical means of analysis and argument, is now and always has been the active philosophy in Christianity ... During the Middle Ages, the golden age of philosophical theology, the vast majority of Christian philosophers contributed to this enterprise. (p. 16)

Contrary to natural theology, therefore, philosophical theology does indeed deal with the central doctrines of the Christian tradition. However, philosophical theology treats these doctrinal propositions as 'assumptions' of which it tries 
to analyse the meaning and not to prove the truth. Unlike natural theology, it seeks not proof but understanding as in the classical theological enterprise of fides quaerens intellectum [faith seeking understanding]. Its primary aim is not to prove the truth of Christian doctrine but rather to illuminate its meaning by analysing its implications and presuppositions and to propose coherent ways in which it could be conceptualised: 'Supporting, elucidating, extending, and connecting propositions of Christian doctrine' (Kretzmann 1989:16).

Whether or not the individual philosophical theologian accepts these assumptions as his or her own is in the end a personal matter. In order to accept the truth of these assumptions with integrity, believers have to recognise this truth through 'experiences of disclosure or discovery which are not the result of human epistemic activity' (Schwöbel 1994:184). At this level, all faith is truly personal. In the words of Smith: 'My faith is an act that I make, myself, naked before God' (Smith 1978:191). Of course, this does not exclude the possibility that others might share my personal faith by recognising it as similar to their own. In fact, all believers have the desire that their own personal faith might correspond to that of others in the community of believers, for only then will they be able to identify with the community without sacrificing their own personal integrity in order to do so. Nevertheless, whether somebody can subscribe to the truth of doctrinal assumptions will finally depend on whether he or she can personally accept these with integrity. We should note, however, that this kind of 'person-relativity' (chapter 2 in Mavrodes 1970) does not only apply to religious beliefs. In a way, it is a general feature of all the beliefs which people hold to be true. In this regard, Augustine was right in pointing out that, however much a pupil can learn from his teacher, there is one thing he must always discover for himself, that is whether what his teacher tells him is true because no one can discern this truth for him in his stead:

If my hearer sees these things himself with his inward eye, he comes to know what I say, not as a result of my words but as a result of his own contemplation. Even when I speak what is true, it is not I who teach him. He is taught not by my words but by the things themselves which inwardly God has made manifest to him. (Augustine 1953:12.40)

The closing words in this quotation suggest that it is here that the concept of revelation comes in. Although all truth claims eventually depend on the personal recognition of those who accept them, religious believers tend, in the light of their faith, to ascribe this recognition to illumination by the Spirit of God. In the words of Calvin, the Spirit 'with a wondrous and special energy, forms the ear to hear and the mind to understand' (Calvin 1953:2.2.20). In this sense, Christian theology in essence rests on faith in the revelation of God.

Recognising the truth of doctrinal assumptions therefore involves an appeal to revelation. However, analysing their meaning does not. Whether or not philosophical theologians recognise the truth of the doctrinal assumptions that they analyse does not directly affect the kind of conceptual questions about presuppositions and implications they address, nor does it affect the kind of philosophical analyses they employ to deal with them. Of course, the personal faith of philosophical theologians could motivate them to ask certain specific questions rather than others and also to analyse the Christian doctrine rather than the doctrines of some other religion or view of life. However, such commitments do not affect the methods or the criteria with which these conceptual issues about the meaning of the Christian doctrine is addressed. The basic intellectual meeting point common to believers and non-believers cannot therefore consist in a common rational basis for recognising the truth of Christian doctrines as is assumed in natural theology. It can however be found in the methods and criteria by which philosophical theologians analyse the meaning of these doctrines.

\section{Meaning and truth}

Unlike natural theology, philosophical theology thus seeks to analyse the meaning of (Christian) doctrine rather than to prove its truth. Nevertheless philosophical theologians are deeply interested in the question of truth because there is a close connection between meaning and truth. If the meaning of a doctrinal proposition is its use, then it is part of the meaning of the proposition to either express or entail truth claims. Analysing the meaning of a religious doctrine therefore includes analysing and evaluating the truth claims expressed or entailed by it.

At this point, it is important to note the contextual nature of meaning (see Brümmer 1993; Brümmer 1999). If the meaning of an utterance is given in its use, this is always its use within a specific context of human life and thought. Thus the meaning of a religious doctrine or proposition cannot be abstracted from the religious language game which is the context of its employment within human life and thought. Such abstraction leads to the 'decontextualisation' against which we have heard Schwöbel (1994) warn us above. This also applies to the truth claims expressed or entailed by such religious doctrines within this context. Thus the justification of religious beliefs is primarily an attempt to demonstrate their legitimacy within the context of the language game of religion. But then our understanding of this language game will determine the nature of the justification we seek to provide.

Since the Enlightenment, Western culture has intuitively tended to reduce all thinking to its epistemic dimensions (see chapter 18 in Brümmer 2006). This tendency has been markedly strengthened by the successes of scientific enquiry. 'How do you know?' has become the basic question dominating all our thinking. Accordingly, the role of religious belief in human life and thought is often thought of in purely epistemic terms. Like science, religion has what Adriaanse calls an 'informative result-orientation' (Adriaanse 1995:175) since it is aimed at providing us with knowledge about the world, human existence and God. Religious beliefs about these matters are taken to be factual hypotheses of a sort that theology is required to test in order to demonstrate 
their theoretical legitimacy. The key issue to be resolved is whether these hypotheses have to be tested in the light of 'revelation' (as is held in revealed theology) or in the light of observation and reason (as is held in natural theology). This view seriously reduces the role of religious belief in human life and thought. I agree with Stenmark's (1998) comment that:

since the relevant aim of religion is then taken to be merely epistemic, the 'theist' whose beliefs are examined, in fact turns out to be a purely epistemic being (a being whose sole concern is believing as many truths and as few falsehoods as possible). But the problem is that actual religious believers - whether Christian or not - are not purely epistemic beings, and it would be irrational for them to be so! ... Actual religious believers are the kind of creatures who live in a world that has dangerous surprises from which their well-being must be secured ... The job religion does is (among other things) to help them find a way of getting through the barriers of suffering and death, guilt and meaninglessness. (p. 278)

Actual religious believers are people who try to make sense of their lives and of their experience of the world by interpreting these in terms of the faith which has been handed down to them in the religious tradition with which they can identify with integrity. Thus Christians understand their lives as meaningful because these are lived in fellowship with God. We are significant beings because God loves us. Our experience of the world is also meaningful because of the many ways in which God is involved in the things we experience. Thus many events are experienced as acts in which God realises his purposes and for which he is to be thanked; other events are experienced as contrary to God's will and therefore to be opposed. Thus life and the world are meaningful because of the way these are related to God. Believers understand this complex relationship between God, themselves and the world in terms of the heritage of conceptual models, metaphors and narratives which has been handed down to them in their own religious tradition. In this way, religious belief is hermeneutical rather than epistemic (see chapter 9 in Brümmer 2008). It is not primarily a way of knowing but a way of understanding that determines the meaning and significance of life and the world. This understanding is existential in the sense that it determines which actions and attitudes are appropriate in relationship to God, the world and other people. Faith is therefore not only a way of understanding but also a way of life in accordance with this understanding. In this way, faith also determines the moral life of believers (chapter 7 in Brümmer 2008; De Villiers 1978).

The claim that religious belief is primarily hermeneutical rather than epistemic does not entail a non-cognitive view of religious belief. Religious belief is primarily a way of understanding, but this way of understanding entails a variety of truth claims about the world, human existence and God. It is important to distinguish here between three kinds of truth claims involved in such religious understanding: empirical claims, claims regarding religious experience and metaphysical claims concerning the existence and attributes of God.
Empirical truth claims are claims which in principle can be (or could have been) verified empirically by anyone. Although empirical claims are not strictly speaking religious claims, religious beliefs often entail such empirical claims. Understanding events in our own lives and experience or in history in terms of our faith presupposes that these events really occurred. Thus Archbishop Usher's religious claim that God created the universe 6000 years ago entails the empirical claim that the universe is 6000 years old. The religious claim that God led the people of Israel out of Egyptian bondage to a Promised Land entails the empirical claim that the Israelites migrated from Egypt to Palestine. The religious claim that Jesus triumphed over death by rising from the grave entails the empirical claim that a dead person was in some way resuscitated. The acceptability of such empirical claims does not depend on religious faith but on empirical tests. If any of these should prove to be mistaken, believers will have to reinterpret their religious beliefs in such a way that they no longer entail such mistaken empirical claims. If such reinterpretation should prove to be impossible, the religious claims in question will lose their credibility. Thus Usher's claim about the age of the universe has been effectively falsified by the findings of astronomy, geology and palaeontology, and most believers today have come to interpret their belief in divine creation in ways that are consistent with scientific findings about the age of the universe. Because of the empirical unlikelihood of the resuscitation of a dead person, many believers tend to also reinterpret the meaning of the resurrection of Jesus in ways that are empirically more plausible. Since the biblical record of the resurrection is by no means clear regarding the precise factual details of the resurrection event (the resurrected Jesus was in many ways a very different kind of being from the Jesus who was crucified), such a reinterpretation is not without some plausibility. However, a resurrection in some form or other, although unlikely, is not logically impossible. Thus Smart (1964) suggests that we:

[i]magine Hume being present at someone's rising from the dead. What does he say to himself? 'Impossible, gentlemen, impossible. This is contrary to all my previous experience of mortality, and to the testimony of countless human beings. It would be a lesser miracle that my eyes deceive me than that this resurrection should have occurred.' Well, perhaps of course his eyes do deceive him. Let him test them. Let him investigate minutely the resurrected body. Can he still doubt? (p. 34)

If a sceptic like Hume is confronted with a situation like this, he might be moved to accept the empirical claim about the resurrection. However, this does not mean that he also has to accept the religious claim about a miraculous divine action. He could also look on the event as an extraordinary and inexplicable anomaly and leave it at that. As the South African theologian Andrew Murray pointed out (Murray $1942: 126,128)$, it is only with the 'eyes of faith' that believers can recognise an (extraordinary or inexplicable) event as an act of God. Without faith such events are mere anomalies without any religious significance. Here too empirical claims regarding such events neither presuppose nor entail any religious belief. It follows that religious truth claims cannot simply be derived from empirical experience as 
natural theology supposes. This will only be possible if such empirical experience has first been understood in terms of faith. Here too religious experience is hermeneutical rather than epistemic. But then the 'proofs' provided by natural theology are circular since the experience on which they are based presuppose the faith which it tries to prove.

Unlike empirical claims, claims about religious experience do presuppose religious belief. Religious believers understand their lives and their experience of the world in terms of the conceptual models and metaphors derived from the religious tradition in which they stand (on the role of religious models and metaphors, see chapter 13 in Brümmer 2006). As we pointed out above, believers experience their own lives as meaningful because, in many ways, these are for them lived in fellowship with God, and the world is meaningful because of the many ways in which they believe God to be involved in what happens in the world. Some events are experienced as gracious acts of God whereas others are contrary to God's will and to be opposed by us. It is clear that believers can only thus experience the world in terms of the providential agency of God in the light of their own anterior beliefs about the will of God. In fact, it is only with the 'eyes of faith' that they can experience events as expressions of divine grace in their lives and in the world rather than as mere inexplicable but fortunate anomalies or coincidences. Religious experience is therefore religiously interpreted experience, and as such, it is not open to empirical verification. For this reason, religious experience cannot provide the universally shared grounds which natural theology requires for its attempt to prove the truth of religious beliefs. As we have argued above, such 'proofs' will always be circular (see chapter 8 in Brümmer 2006). This does not mean that such religious interpretations are immune to criticism. Such criticism is, however, internal to the religious beliefs in terms of which the interpretation takes place. Within the religious tradition, it remains a point of discussion whether the interpretation is valid or not. Thus for example, it always remains an open question whether it is consistent with the faith to understand an event as one in which God realises his purposes.

Metaphysical claims about the existence and nature of God are obviously not open to empirical verification since God is not an empirically observable object. Since God lives in an 'unapproachable light', no one has ever seen or can ever see him (1 Tm 6:16, Jn 1:18). Neither can such claims be derived from empirical experience as natural theology supposes. For the same reason, such claims about God are also not claims about religious experience in the above sense. In the light of faith, we could experience the world as an expression of the grace of God or as the context within which we are called to do God's will but not as an experience of God as such. In this respect too, he 'lives in an unapproachable light'. Nevertheless such claims about God can be derived from religious experience in our lives and the world, in the sense that they are the constitutive presuppositions of such experience and of the way of life entailed by it (on 'constitutive presuppositions' see chapter 10 in Brümmer 2008). I logically cannot claim to live my life in fellowship with God without presupposing that God really exists and is the kind of being with whom such fellowship is possible. Also I logically cannot experience the world as an expression of God's grace and as the context in which I am called to do God's will without presupposing that God exists (on the concept of 'existence' applied to God, see chapter 17 in Brümmer 2006) and is in some way active as an agent in the world (on the concept of divine agency, see chapters 8 and 26 in Brümmer 2006). Although such claims about the existence and agency of God are not empirical claims open to empirical verification or falsification, this does not mean that they are immune to criticism. Such criticism is, however, internal to the religious understanding and way of life which is constituted by these claims. Within a religious tradition, it always remains a point of discussion whether our beliefs about God are indeed such as are constitutive for the way of life and understanding which is given in the faith.

Distinguishing and critically evaluating these various kinds of truth claims within a religious tradition is clearly part of the philosophical theologian's 'ongoing project of supporting, elucidating, extending and connecting propositions of Christian doctrine by the standard philosophical means of analysis and argument' (Kretzmann 1989:16). However, such critical evaluation and rational justification always takes place within the context of the tradition of faith in terms of which believers make sense of their lives and experience. The critical question is always whether this religious understanding of experience or that metaphysical claim about the existence and nature of God is coherent with the tradition of faith. These truth claims cannot be decontextualised and evaluated as though they were simple empirical claims.

At this point, we might have the uncomfortable feeling that, in the end, this kind of philosophical theology fails to avoid the fideistic implications of revealed theology. After all, if the truth claims of religion can only be evaluated and justified critically within the context of a tradition of faith, does this not withdraw theology into the intellectual ghetto of revealed theology? Can this suspicion of fideism be removed?

\section{Philosophical theology and fideism}

Although the truth claims of religion can only be justified within the context of a tradition of faith, this would only entail a form of fideism if the tradition of faith as such were somehow immunised from criticism, doubt and rejection. That would only be the case if a tradition of faith were an immutable and indubitable system of ideas, and if furthermore it were somehow isolated from and thus unaffected by all other aspects of human life and thought in a way that would immunise it from outside influences. This would, however, be a serious misunderstanding of the nature of religious traditions.

All language games, including the language game of religion, are subject to historical and cultural change. Changes in the factual circumstances of our lives and in the problems and demands with which life confronts us give rise to changes in 
our culture and thus also in the forms of thought which we find adequate, the language games in which these forms of thought find expression and in the concomitant beliefs which we hold to be true. The more we become aware of the cultural differences between different times and places, the more we realise the untenability of the platonic view that human thought is essentially timeless and immutable. Because of changes in the demands of life, our forms of thought can never remain adequate for all time. In this sense, we can understand Wittgenstein's claim that the multiplicity of language games 'is not something fixed, given once for all; but new types of language, new language games, as we may say, come into existence, and others become obsolete and forgotten' (Wittgenstein 1953:I.23). Elsewhere Wittgenstein (1980) illustrates this point as follows:

Earlier physicists are said to have found suddenly that they had too little mathematical understanding to cope with physics; and in almost the same way young people today can be said to be in a situation where ordinary common sense no longer suffices to meet the strange demands life makes. Everything has become so intricate that mastering it would require an exceptional intellect. Because skill at playing the game is no longer enough; the question that keeps coming up is: can this game be played at all now and what would be the right game to play? (p. 27)

In this sense, Wittgenstein clearly admits that language games and the forms of life in which they are embedded are not immutable nor are they isolated from other aspects of our life and thought. For this reason, language games are not immune from criticism. They can be contested in the light of the changing demands of life.

Clearly this also applies to the language game of religion which is always embedded in an ongoing religious tradition. Such a tradition is not an immutable and isolated system of religious ideas. It is rather an historical process of transmission with a Wirkungsgeschichte and as such characterised by pluralism and change. Smith (chapter 6 in Smith 1978) shows how this process has a 'cumulative character'. In a process of socialisation, religious believers receive from the past a religious heritage in the form of rites and practises; beliefs and norms; ideas and ideals; group pressure and family influences; vocabulary, metaphors and conceptual models; assumptions; social institutions; etc. This heritage includes the totality of conceptual forms in which their predecessors expressed in thought and action the faith that they in turn had received from their predecessors and in terms of which they interpreted their own lives and experience meaningfully. The heritage which they handed down to their successors was however not identical with what they had received. Changes in the circumstances and demands of life require changes and shifts in the way they understand their faith. Other aspects of the heritage of faith become relevant and necessary for believers to make sense of their lives and experience, and to do this adequately, they may also come to interpret these aspects of the heritage in ways which differ from that of their predecessors. By appropriating the heritage of faith and by expressing it again in their own time and circumstances, believers reconceptualise the heritage by adding their own conceptual form to it. In this way, a religious tradition is a cumulative process of interaction between the heritage from the past and the personal faith of believers who make the heritage their own. Obviously, the heritage of faith does not include the faith of later generations. This is added to the heritage of faith in the cumulative process of the tradition. The personal faith of believers is conditioned by the heritage but not completely determined by it. The personal faith of every believer adds his or her own authentic reconceptualisation to the heritage.

It is clear that every tradition of faith, if it is to remain alive, must have the capacity for reconceptualising its heritage in ways that are logically coherent, relevant and adequate to the changing circumstances and demands of life, intelligible to the community of believers and credible in the light of the current state of knowledge (on the need for such reconceptualisation, see chapter 35 in Brümmer 2006). If for some reason, it should lose this capacity for renewal, a tradition of faith will become obsolete and forgotten. In the words of Fried, those who want the world to stay as it is, do not want it to stay (Fried 1994). In this way, the ancient fertility cults in the Mediterranean basin were so strongly embedded in an agrarian way of life that they could not survive the rise of trade, industry and the urbanisation of society. They proved quite inadequate as means of making sense of these changed circumstances in the lives of people (Kuitert 1977:144-145). On the other hand, those world religions that have remained relevant throughout the ages in spite of great changes in the culture and circumstances in the lives of their adherents could only remain so to the extent that they had the capacity for change and reconceptualisation.

This has profound implications for the way in which philosophical theology tries to analyse the heritage of faith. Changes in the demands of life bring about changes in the aspects of the heritage which are relevant and necessary in order to make sense of life and cope meaningfully with our experience of the world. At different times and in different cultural situations, philosophical theology should therefore develop different conceptual models in order to highlight those aspects of the faith which are relevant to the cultural and historical situation and in order to filter out those aspects which are not relevant to the current demands of life. McFague (1987) provides a good example to illustrate this point:

In an era when evil powers were understood to be palpable principalities in contest with God for control of human beings and the cosmos, the metaphor of Christ as the victorious king and lord, crushing the evil spirits and thereby freeing the world from their control, was indeed a powerful one. In our situation, however, to envision evil as separate from human beings rather than as the outcome of human decisions and actions, and to see the solution of evil as totally a divine responsibility, would be not only irrelevant to our time and its needs but harmful to them, for that would run counter to one of the central insights of the new sensibility: the need for human responsibility in a nuclear age. In other words, in order to do theology, one must in each epoch do it differently. To refuse this task is to settle for a theology appropriate to some other time than one's own. (pp. 29-30) 
It is now clear that the philosophical theologian's 'ongoing project of supporting, elucidating, extending and connecting propositions of Christian doctrine by the standard philosophical means of analysis and argument' (Kretzmann 1989:16) cannot be merely descriptive, but it must be both critical and innovative as well. It should not merely describe the conceptual grammar of Christian doctrine, but it should also develop innovative proposals that are coherent, credible, intelligible, relevant and adequate to enable believers to cope with integrity with the changing demands of life (on the innovative task of philosophical theology, see chapters 35 and 40 in Brümmer 2006). In this way, philosophical theology has an essential task to fulfil in service of the community of believers.

The fact that philosophical theology serves the community of believers in this way does not entail a retreat into an intellectual ghetto. Coherence, credibility, intelligibility, relevance and adequacy are after all external criteria that apply to every religion and also to secular views of life that function for many as alternatives for religious belief (on the intersubjectivity of these criteria, see chapter 41 in Brümmer 2006). They provide basic intellectual meeting-points common to believers and non-believers in the light of which the philosophical theologian seeks to justify the religious heritage and the beliefs entailed by it. It is clear that religious believers cannot ignore the criticism from outsiders that their faith fails to fulfil these requirements. Nor can they ignore the challenge from outsiders to show that their heritage can be conceptualised in ways that do. In this sense, philosophical theologians cannot rest content with merely analysing and describing the beliefs entailed within the context of a religious heritage. They are also bound to demonstrate that this heritage and the beliefs it entails are theoretically justified since they fulfil the common criteria of rationality. Furthermore this justification should not only be directed at fellow believers but also at outsiders who do not share the same heritage of faith. Of course such a justification does not amount to a knock-down proof which would force the outsiders to accept to the heritage of faith. Although coherence, credibility, intelligibility, relevance and adequacy are necessary conditions for accepting the heritage of faith, they are not sufficient. In the final analysis, the decision to ascribe to the heritage of faith is not merely intellectual but also existential. As we have argued above, everyone must personally come to recognise that he or she can appropriate the heritage of faith with integrity. No amount of intellectual argument can force this recognition on anybody (on the limits of rational argument, see Brümmer 1981:136-142 and chapter 40 in Brümmer 2006).

Although the general limits of rationality also apply to this dialogue with outsiders, it is nevertheless an essential part of the project of philosophical theology. We have argued, however, that this dialogue should not be construed as one about the truth of decontextualised religious propositions as is the case in natural theology. On the contrary, it is primarily a dialogue about the theoretical legitimacy of a view of life as such and only in a derived sense about the truth of its constitutive presuppositions. Thus the theoretical legitimacy of truth claims about the existence of God can only be meaningfully discussed within the context of the religious view of life with which one can identify with integrity. Atheists who reject the claim that theistic faith is coherent, credible, intelligible, relevant or adequate for coping with the demands of life feel no need for the presupposition that God exists, which is constitutive for this faith. It is up to them, therefore, to reflect on the form of life they could authentically adopt and on the presuppositions constitutive of it. Christian theists, however, hold that the Christian faith can be coherently, credibly and intelligibly conceptualised in a form that is relevant and adequate for making sense of the demands with which life confronts them. If for this reason they can authentically make this form of life their own, then it is for them absurd to deny the truth of its constitutive presupposition, namely that the God in whose sight they live and move and have their being, exists in reality.

\section{Acknowledgements}

The author declares that he has no financial or personal relationship(s) which may have inappropriately influenced him in writing this paper.

\section{References}

Adriaanse, H.J., 1995, Vom Christentum aus, H.J. Kok, Kampen.

Augustine, 1953, De Magistro, in J.H. Burleigh (ed.), Augustine: Earlier writings, pp. 64-105, The Westminster Press, Philadelphia.

Austin, W.H., 1967, Waves, particles and paradoxes, Rice University Studies, Austin. Brümmer, V., 1981, Theology and philosophical inquiry, Macmillan, London.

Brümmer, V., 1992, Speaking of a personal God, Cambridge University Press, Cambridge.

Brümmer, V., 1993, 'Wittgenstein and the irrationality of rational theology', in J.M. Byrne (ed.), The Christian understanding of God today, pp. 88-102, Columba Press, Dublin.

Brümmer, V., 1999, 'How rational is rational theology? A reply to Mikael Stenmark', Religious Studies 35, 89-97. http://dx.doi.org/10.1017/\$0034412598004727

Brümmer, V., 2006, Brümmer on meaning and the Christian faith. Collected writings of Vincent Brümmer, Ashgate Publishers, Aldershot.

Brümmer, V., 2008, What are we Doing when we Pray? On Prayer and the Nature of Faith, Ashgate Publishers, Aldershot.

Calvin, J., 1953, Institutes of the Christian religion, James Clarke \& Co, London.

De Villiers, D.E., 1978, Die eiesoortigheid van die Christelike moraal, Rodopi, Amsterdam.

Fried, E., 1994, Quoted by Walter Goddijn N.R.C. Handelsblad, 01 August 1994.

Jeffner, A., 1986, Theology and integration, Almqvist \& Wiksell International, Stockholm

Kretzmann, N., 1989, 'Reason and mystery', in G. Vesey (ed.), The philosophy of Christianity, pp. 15-39, Cambridge University Press, Cambridge.

Kuitert, H.M., 1977, Wat heet geloven? Ten Have, Baarn.

MacFague, S., 1987, Models of God, S.C.M. Press, London.

Mavrodes, G.I., 1970, Belief in God, Random House, New York.

Murray, A., 1942, Die moderne ongeloof, Christen-Studentevereniging van S.A., Stellenbosch.

Schwöbel, C., 1994, 'After post-theism', in S. Andersen (ed.), Traditional theism and its modern alternatives, pp. 160-196, Aarhus University Press, Aarhus.

Smart, N., 1964, Philosophers and religious truth, S.C.M. Press, London.

Smith, W.C., 1978, The meaning and end of religion, S.P.C.K., London.

Stenmark, M., 1998, 'The end of the theism-atheism debate? A response to Vincent Brümmer', Religious Studies 34, 261-280. http://dx.doi.org/10.1017/ S0034412598004430

Wittgenstein, L., 1953, Philosophical investigations, Oxford University Press, Oxford. Wittgenstein, L., 1980, Culture and value, Oxford University Press, Oxford. 